\title{
Potensi Limbah Jagung Hibrida (Zea mays L) sebagai Pakan Ternak di Daerah Dataran Kering Provinsi Nusa Tenggara Timur
}

The Potential of Corn Hybrid Waste (Zea mays I) as Livestock Feed in Dry Land, Province of Nusa Tenggara Timur

\section{Y Achadri, E Y Hosang, P R Matitaputty, C J B Sendow}

Corresponding email: yanachadri1988@gmail.com yanuarachadri@pertanian.go.id

Balai Pengkajian Teknologi Pertanian (BPTP) Nusa Tenggara

Timur, Indonesia

Submitted: $21^{\text {st }}$ May 2021 Accepted : $31^{\text {st }}$ July 2021

\section{ABSTRACT}

Corn waste agricultural by-product that can be used for animal feed at Nusa Tenggara Timur (NTT) has a longer dry climate than the rainy ones, caused difficulties in terms of feeding. Farmers utilize corn waste as feed resource. This study was carried out to determine the potential corn waste and evaluate the potential capacities of livestock from corn waste as animal feed. The data was obtained from farmer group, collected during December 2019 to April 2020 in Oeteta Village, Kupang Timur - NTT. The data of corn waste material production included corn straw (stalks and leaves), corn cob, and corn husk in 7 hectares area. Data were collected by using the survey with simple random sampling for estimation of carrying capacity value. The results showed that the fresh corn waste production on the land area of 7 hectares in the Oeteta village were fresh corn straw $\left(451,101 \mathrm{~kg}\right.$ year-1), corn cob $\left(65,225.58 \mathrm{~kg}^{-1}\right.$ year-1), corn husk $\left(10,870.86 \mathrm{~kg}\right.$ year-1 $\left.^{-1}\right)$, and total $527,197.44 \mathrm{~kg}_{\text {year-1 }}$ of corn waste production. Utilization of corn waste as feed stock with the use of $30 \%$ in the ration generated a carrying capacity of 352 cattle and 2,464 goats respectively, have a carrying capacity 352 head of beef cattle and 2,464 head of goats, whereas if the use was $40 \%$ in the ration, the carrying capacity was 264 cattle and 1,851 goats. It could be concluded that the feed from corn waste available in Oeteta Village, Kupang Regency, NTT, which is 7 ha of area have sufficient carrying capacity for livestock.

Key words: carrying capacity, corn waste, Oeteta Nusa Tenggara Timur

\section{ABSTRAK}

Limbah jagung (Zea mays L) merupakan sisa hasil produksi pertanian yang dimanfaatkan untuk pakan ternak. Nusa Tenggara Timur (NTT) mempunyai iklim kering yang mengakibatkan kesulitan ternak dalam mendapatkan pakan, sehingga banyak peternak memanfaatkan limbah jagung sebagai pakan ternak. Tujuan penelitian ini adalah mengetahui potensi limbah jagung dan potensi kapasitas ternak dari limbah jagung di Desa Oeteta, Kec. Kupang Timur, NTT. Penelitian dilakukan pada bulan Desember 2019 hingga April 2020. Metode penelitian yang digunakan survey dengan simple random sampling. Hasil penelitian menunjukkan bahwa ketersediaan limbah pakan jagung dalam bentuk limbah segar berdasarkan luas lahan 7 hektar di Desa Oeteta adalah jerami jagung dalam bentuk segar (451.101 kg tahun $\left.{ }^{-1}\right)$, tongkol jagung (65.225,58 kg tahun $\left.{ }^{-1}\right)$, dan kelobot jagung $\left(10.870,86 \mathrm{~kg} \mathrm{tahun}^{-1}\right)$, sehingga total produksi limbah jagung eksisting sebesar 527.197,44 kg tahun ${ }^{-1}$ Pemanfaatan limbah jagung sebagai pakan dengan penggunaan sebanyak 30\% dalam ransum secara berturut-turut menghasilkan kapasitas tampung sebanyak 352 ekor ternak sapi dan 2.464 ekor kambing, sedangkan jika penggunaan sebanyak 40\% maka kapasitas tampung sebanyak 264 ekor ternak sapi dan 1.851 ekor kambing. Berdasarkan hasil penelitian dapat disimpulkan bahwa pakan dari limbah jagung yang tersedia di Desa Oeteta, Kabupaten Kupang, NTT, yaitu luasan lahan 7 ha dapat mencukupi daya kapasitas tampung untuk pakan ternak.

Kata kunci: kapasitas tampung, Oeteta Nusa Tenggara Timur, produksi limbah jagung 


\section{PENDAHULUAN}

Provinsi Nusa Tenggara Timur (NTT) sebagian besar wilayahnya bergunung dan berbukit, hanya sedikit dataran rendah, terdiri atas 22 wilayah kabupaten / kota dan 306 wilayah kecamatan (BPS NTT, 2020). Nusa Tenggara Timur dikenal mempunyai dua musim, yaitu musim kemarau dan musim hujan. Pada bulan Juni sampai September, arus angin berasal dari Australia dan tidak banyak mengandung uap air sehingga terjadi musim kemarau. Sebaliknya pada bulan DesemberMaret, arus angin yang berasal dari Asia dan Samudera Pasifik banyak mengandung uap air sehingga terjadi musim hujan. Keadaan seperti ini berganti setiap setengah tahun setelah melewati masa peralihan pada bulan April-Mei dan Oktober-November (BPS NTT 2020). Namun, mengingat NTT dekat dengan Australia, arus angin yang banyak mengandung uap air dari Asia dan Samudera Pasifik tersebut, setelah sampai di wilayah NTT kandungan uap airnya sudah berkurang sehingga hari hujan di NTT lebih sedikit dibanding wilayah yang dekat dengan Asia. Hal ini menjadikan NTT sebagai wilayah beriklim kering dengan 4 bulan basah (Desember-Maret) dan 8 bulan kering, bahkan pada bulan Agustus - September sering tidak turun hujan. Berdasarkan curah hujan dan hari hujan, wilayah NTT memiliki curah hujan rendah dan hari hujan yang pendek.

Kondisi demikian akan berpengaruh terhadap sistem usaha tani dan vegetasi yang tumbuh di lokasi, yakni komoditas unggulan jagung yang dimanfaatkan sebagai bahan pangan pokok sebagian besar masyarakat di NTT. Hal demikian tentu akan berdampak terhadap pengembangan peternakan, terutama ketersediaan hijauan. Pengembangan ternak sangat ditentukan oleh daya dukung wilayah, khususnya ketersediaan pakan berupa hijauan pakan (rumput dan leguminosa) dan limbah pertanian/perkebunan. Hijauan pakan ternak dapat bersumber dari rumput alam maupun rumput yang dibudidayakan, selain dari padang penggembalaan (Priyanto, 2016).

Kebutuhan protein hewani khususnya daging untuk konsumsi masyarakat sangat tinggi, sehingga produksi ternak harus ditingkatkan. Hal ini dapat dicapai dengan meningkatkan efisiensi produktivitas ternak secara keseluruhan dalam berbagai aspek. Efisiensi produksi peternakan akan tergantung pada ketersediaan pakan berkualitas atau pakan ternak dalam jumlah yang cukup sepanjang tahun. Salah satu upaya pengembangan peternakan adalah penyediaan pakan yang murah dan mudah didapat serta tersedia sepanjang tahun. Saat ini, biaya pemeliharaan pakan ternak masih cukup tinggi karena kenaikan biaya bahan bakar, pupuk, serta semakin meningkatnya kondisi cuaca ekstrim. Maka dari itu, dibutuhkan sumber bahan pakan alternatif untuk pakan ternak, limbah pertanian dapat menjadi salah satu sumber alternatif pakan ternak (Rivin et al. 2014).

Jagung (Zea mays L) merupakan salah satu limbah pertanian yang potensial sebagai pakan ternak. Limbah jagung pada dasarnya merupakan bahan yang dihasilkan dari produk sisa hasil panen pertanian. Jagung adalah tanaman semusim dan termasuk jenis rumputan/ graminae yang mempunyai batang tunggal, meski terdapat kemungkinan munculnya cabang anakan pada beberapa genotipe dan lingkungan tertentu. Jagung merupakan tanaman hari pendek, jumlah daunnya ditentukan pada saat inisiasi bunga jantan, dan dikendalikan oleh genotipe, lama penyinaran, dan suhu. Jagung sangat disukai oleh ternak, memenuhi syarat sebagai sumber energi, mudah disimpan, mudah diproduksi secara besar-besaran, mudah digunakan bersama bahan makanan lain, dan jagung kuning merupakan sumber karoten yang baik. Kekurangan dari jagung adalah defisien akan kandungan protein, sehingga harus selalu digunakan bersama dengan sumber protein seperti bungkil-bungkilan atau hijauan leguminosa.

Pertanian merupakan salah satu sektor hayati terbesar dengan produksi biomassa tertinggi (EC 2015), yang menjadi input penting bagi ekonomi petani peternak (Bracco et al. 2018). Limbah pertanian bukan merupakan produk primer seperti limbah jagung yang terdiri dari sisa batang, jerami, daun, akar, sekam, cangkang dan sebagainya. Limbah pertanian merupakan produk sisa hasil pertanian yang banyak tersedia, sumber daya terbarukan, mudah didapat, dan bahan yang murah atau gratis. Jadi, ini bisa menjadi sumber daya yang penting (Sabiti 2011).

Limbah tanaman jagung merupakan sisa hasil pertanian yang didapat setelah panen yang terdiri dari sisa daun (jerami), batang jagung, tongkol, kulit buah (klobot). Limbah jagung yang paling banyak limbahnya adalah brangkasan jagung (daun, akar, batang) dengan tingkat kecernaan yang rendah. Sekam jagung merupakan limbah terkecil namun memiliki daya cerna yang tinggi dibandingkan limbah jagung lainnya. Limbah tanaman jagung segera dipanen setelah benih tongkol jagung mulai masak dan siap dipanen sebelum residu kehilangan air. Jagung merupakan salah satu komoditas strategis dalam penyediaan pangan sumber karbohirat dan juga penting terkait dengan industri peternakan dalam negeri yang terus diupayakan hingga saat ini. Sektor peternakan terus berkembang dan menyumbang 40-50\% dari PDB pertanian (Herrero et al. 2016).

Jerami jagung sebagai pakan ternak ruminansia banyak digunakan terutama sebagai pengganti sumber serat atau menggantikan $50 \%$ dari rumput atau hijauan. Penggunaan jerami jagung harus diimbangi dengan pemberian konsentrat, sehingga kebutuhan ternak dapat terpenuhi. Tongkol jagung memiliki kandungan serat kasar yang tinggi, rendah akan kandungan protein kasar, mineral, vitamin, dan tidak memiliki karoten, sehingga dalam pemanfaatannya perlu disuplementasi dengan bahan pakan sumber protein, energi dan mineral agar dapat memenuhi kebutuhan hidup pokok dan pertumbuhan ternak ruminansia. Klobot Jagung merupakan salah satu limbah tanaman jagung yang 
dapat dijadikan makanan ternak ruminansia. Klobot jagung selain berfungsi sebagai makanan ternak juga berfungsi sebagai pelindung biji jagung dan tongkol, untuk mempertahankan kesegaran sehingga tidak akan terlampau keras untuk dikunyah oleh ternak, bersama dengan tongkol bersifat sebagai hijauan, oleh karena itu buah jagung lengkap lebih disukai dibanding dengan biji jagung (Parakkasi, 2006).

Salah satu kendala yang dihadapi dalam perkembangan ternak di NTT khususnya di Desa Oeteta, Kabupaten Kupang adalah rendahnya ketersediaan hijauan pakan ternak terutama pada musim kemarau. Hal ini menyebabkan produktivitas ternak menurun dan tidak sedikit peternak yang menjual ternaknya dengan harga yang relatif lebih murah dibandingkan pada musim hujan. Menurut Keban (2019), bahwa wilayah NTT didominasi oleh pertanian lahan kering, kondisi iklim di NTT untuk musim kemarau lebih lama (8-9) bulan dibandingkan musim hujan (3-4) bulan. Sistem usaha tani di NTT didominasi oleh usaha tani lahan kering dengan sistem usaha tani tradisional. Sistem pertanian tradisional dilakukan oleh petani dengan melepas sapi untuk mencari pakan sendiri di lahan penggembalaan umum pada siang hari dan dikandangkan pada malam hari. Hal ini dapat berimplikasi pada produksi pakan yang berjalan relatif lambat. Menurut Kapa (2019), faktor-faktor penyebab berbagai masalah dalam pengembangan sistem usaha tani lahan kering dengan pola curah hujan yang pendek dan tidak merata.

Para petani di Indonesia bagian timur secara tradisional mengandalkan produksi tahunan tanaman jagung dan ternak. Tingkat produksi sapi rendah karena pemberian pakan hijauan lokal dengan daya cerna protein rendah juga saat musim kemarau. Hal ini menyebabkan ternak mengalami penurunan berat badan, terutama pada periode September-November, hingga $60 \%$ bobot yang diperoleh saat musim hujan bisa hilang pada saat akhir musim kemarau dan awal musim hujan. Hal ini mengakibatkan tingkat produksi keseluruhan yang sangat rendah, dengan pertambahan bobot badan tahunan pada sapi kurang dari $200 \mathrm{~g}$ hari $^{-1}$, untuk mencapai kecukupan produksi ternak, baik kualitas maupun kuantitas pakan yang ditawarkan harus ditingkatkan (Nulik, 2013). Integrasi antara tanaman pangan dengan ternak merupakan salah satu alternatif untuk meningkatkan populasi ternak (Rahman, 2015). Penerapan sistem ini agar ternak mendapatkan pakan alternatif dari limbah pertanian dan perkebunan.

Limbah pertanian merupakan sumber pakan murah yang dapat digunakan sebagai pakan substitusi ternak ruminansia. Sumber limbah pertanian diperoleh dari komoditas tanaman pangan. Jenis limbah pertanian yang dapat dimanfaatkan sebagai sumber pakan adalah jerami jagung, tongkol jagung dan sekam jagung. Hal ini menjadi latar belakang penulis melakukan penelitian tentang potensi dan prospek pemanfaatan limbah jagung sebagai pakan ternak yang dilakukan di Desa Oeteta, Kabupaten Kupang, Provinsi NTT. Penelitian ini bertujuan untuk mengukur potensi limbah jagung sebagai pakan ternak di daerah dataran kering Provinsi NTT.

\section{METODE}

\section{Waktu dan Tempat}

Penelitian dilaksanakan selama 5 bulan yaitu, bulan Desember 2019 hingga April 2020. Lokasi di kelompok tani Sehati di Desa Oeteta, Kabupaten Kupang, Nusa Tenggara Timur (NTT). Luas lahan sawah yang digunakan untuk penelitian adalah 7 (tujuh) hektar.

\section{Prosedur Penelitian}

Metode penelitian adalah survei dan pengolahan data dengan metode simple random sampling (Ardiana, 2015). Areal survei lahan produksi jagung adalah tanam 20 hektar. Lahan tersebut diolah dan dibagi menjadi 3 petak (2,5 m x $6 \mathrm{~m})$. Penanaman jagung hibrida dengan jarak tanam $70 \mathrm{~cm}$ x $20 \mathrm{~cm}$ (1 tanaman per lubang). Pemberian pupuk kompos sebanyak $200 \mathrm{~kg}$ pada saat pengolahan lahan sebelum tanam, pupuk NPK $200 \mathrm{~kg}$ dan pupuk urea $200 \mathrm{~kg}$ pemberian pupuk diberikan pada umur 45 hari. Perawatan penyiangan sebelum tanam (pra tumbuh) dan 2 minggu setelah tanam (purna tumbuh). Pengendalian hama secara terpadu pada saat terjadi serangan hama dengan pestisida.

Pengumpulan data pada penelitian ini dilakukan dengan metode kuantitatif dan deskriptif. Data kuantitaif dengan simple random sampling sedangkan data deskriptif melalui wawancara dengan petani. Simple random sampling yaitu pengambilan sampel acak sederhana, pengambilan sampel secara acak tanpa memperhatikan strata dalam populasi. Data tersebut terdiri dari data primer dan data sekunder. Data primer meliputi informasi tentang lahan pertanian yang meliputi objek penelitian, misalnya luas tanam jagung, luas panen jagung, dan produksi limbah tanaman jagung yang dihasilkan (jerami jagung, tongkol jagung dan klobot jagung). Produksi limbah jagung diperoleh dengan melakukan penimbangan berat segar. Selain itu, data primer diperoleh dengan melakukan wawancara dengan petani menggunakan kuesioner (Ardiana, 2015). Pengumpulan data sekunder berupa data luas lahan pertanian, luas lahan jagung yang diperoleh di Gabungan Kelompok Tani (Gapoktan) Desa Oeteta.

Tata cara penghitungan limbah jagung untuk bahan pakan ternak, yaitu dengan penentuan lokasi pengambilan sampel limbah jerami jagung dari masingmasing lokasi panen berdasarkan metode simple random sampling yaitu pengambilan data secara acak karena populasi sampel yang akan diambil homogen. Lahan jagung yang diambil sebagai sampel adalah lahan jagung yang sedang dipanen. Mengukur luas lahan untuk diambil lahan jagung sebagai sampel jerami jagung. Pengambilan data menggunakan bujur sangkar $3 \mathrm{~m} \times 3 \mathrm{~m}$ sebanyak 5 blok per ha. Caranya, potong bagian batang bawah jagung kemudian sampel jerami jagung ditimbang. Perhitungan produksi limbah jagung dengan rumus:

Produksi setiap ubin $=3 \mathrm{~m} \times 3 \mathrm{~m}$.

Produksi setiap hektar $=$

$\frac{1 \text { ha area }}{\text { sampel area }} x$ produksi setiap ubin 
Produksi per tahun $=$

Produksi pakan ha-1 $\mathrm{x}$ Luas areal $\mathrm{x} \sum$ panen tahun ${ }^{-1}$ Menghitung carrying capacity / kapasitas tampung limbah pakan ternak dari data:

Kapasitas tampung $=\frac{\text { produksi pakan }(\mathrm{kg} \text { per tahun })}{\text { konsumsi pakan }(\mathrm{kg} \text { per tahun })}$

Variabel yang diukur dalam penelitian ini adalah produksi limbah jagung seperti jerami jagung (batang dan daun), tongkol jagung, dan klobot jagung berdasarkan luas tanam jagung dan kapasitas tampung atau daya tampung berdasarkan produksi limbah tanaman jagung. Data yang diperoleh dianalisis secara deskriptif. Kapasitas tampung adalah kemampuan suatu wilayah untuk memelihara ternak berdasarkan jumlah hijauan atau produksi limbah pertanian (Pomolango et al. 2016). Analisis kapasitas tampung sapi dihitung berdasarkan produksi bahan kering yang dibandingkan dengan konsumsi pakan ternak (basis bahan kering) selama 365 hari (Abadi et.al, 2019).

\section{HASIL DAN PEMBAHASAN}

\section{Ketersediaan Pakan dari Limbah Jagung}

Salah satu limbah tanaman jagung yang dapat dimanfaatkan sebagai pakan ternak adalah jerami jagung. Limbah sebagai bahan pakan selalu dikaitkan dengan harga yang murah dan kualitas yang rendah, namun nyatanya ada beberapa hal yang perlu diperhatikan sebelum limbah dijadikan pakan ternak, seperti ketersediaan, kandungan nutrien, kemungkinan adanya faktor pembatas seperti zat beracun atau zat anti nutrisi, dan perlu atau tidaknya bahan tersebut diolah sebelum dapat digunakan sebagai pakan. Salah satu jenis limbah yang sering diberikan pada ternak ruminansia adalah limbah tanaman jagung yang meliputi jerami jagung (batang dan daun), tongkol jagung dan kulit jagung (klobot).

Hasil penelitian produksi limbah jagung di Desa Oeteta, Kabupaten Kupang, NTT (Tabel 1) menunjukkan bahwa produksi jerami (batang dan daun) sebanyak $32.221,5 \mathrm{~kg}^{-1}$, tongkol 4.658,97 $\mathrm{kg} \mathrm{ha}^{-1}$, dan kulit jagung (klobot) 776,49 kg ha-1. Produksi limbah tanaman pertanian seperti jagung, jumlah produksinya sangat bergantung pada banyaknya panen yang dihasilkan selama satu tahun, sehingga dapat mendukung kemampuan petani dalam memberikan pakan hijauan saat musim kemarau. Menurut Adijaya et al. (2018) menyatakan bahwa produksi dan hasil varietas jagung sangat dipengaruhi oleh kondisi lingkungan, semakin tinggi adaptasi varietas terhadap lingkungannya maka

Tabel 1 Produksi limbah jagung jenis benih hibrida NASA-29 di Desa Oeteta, Kabupaten Kupang, NTT

\begin{tabular}{lc}
\hline Limbah Jagung segar & Produksi limbah jagung $\left(\mathrm{kg} \mathrm{ha}^{-1}\right)$ \\
\hline Jerami (batang dan & $32.221,5 \pm 12.438,88$ \\
daun) & \\
Tongkol & $4.658,97 \pm 486,07$ \\
Kulit jagung (klobot) & $776,49 \pm 81,01$ \\
\hline
\end{tabular}

pertumbuhan akan meningkat yang ditandai dengan peningkatan massa bio tanaman dan peningkatan komponen hasil tanaman. Kemampuan menghasilkan dari tumbuhan sangat ditentukan oleh kemampuan tumbuhan dalam memanfaatkan faktor pertumbuhan yang ditransplantasikan ke organ penyimpan. Sumber dalam bentuk asimilasi yang dihasilkan dari proses fotosintesis memegang peranan penting dalam hal ini. Daun tanaman sebagai organ yang berfungsi dalam proses fotosintesis akan berfungsi secara optimal jika faktor pembatas dapat diminimalisir. Fotosintesis yang dihasilkan jagung sangat dipengaruhi oleh indeks luas daun (ILD).

Produksi limbah jagung yang dihasilkan tanaman jagung di Desa Oeteta, Kabupaten Kupang, NTT selama satu tahun adalah 527.197,44 kg tahun ${ }^{-1}$ terlihat pada Tabel 2. Hasil tersebut menunjukkan bahwa produksi limbah jagung di Desa Oeteta-Kupang NTT cukup tinggi, sehingga dapat digunakan sebagai pakan alternatif ternak ruminansia seperti sapi pada musim kemarau. Pemanfaatan limbah pertanian sebagai bahan pakan ternak merupakan alternatif dalam upaya pemenuhan nutrienternak. Dua aspek terkait pemanfaatan limbah sebagai pakan ternak adalah ketersediaan bahan pakan ternak sebagai bahan baku yang bernilai ekonomis tinggi dan membantu mengurangi pencemaran lingkungan. Pemanfaatan limbah tanaman jagung sebagai pakan dalam bentuk segar paling mudah dan murah, namun pada saat panen hasil limbah tanaman jagung cukup melimpah sehingga sebaiknya disimpan untuk pakan ternak pada musim kemarau panjang atau pada saat hijauan kurang. Produksi berbagai limbah jagung pada setiap panen dipengaruhi oleh beberapa faktor yaitu varietas jagung yang ditanam, jarak tanam, pemberian pupuk, panen dan penanganan pascapanen. Namun produksi tanaman terancam oleh hama (misalnya penggerek batang, ulat grayak dan striga) (Midega et al. 2018), infertilitas tanah(Kaizzi et al. 2017), cuaca yang tidak dapat diandalkan dan efek perubahan iklim (Bryan et al. 2013).

Dalam pelaksanaan penelitian ini tanaman jagung yang diamati adalah jagung dengan varietas atau jenis benih hibrida NASA-29. Petani menanam jagung hibrida

Table 2 Produksi limbah jagung jenis benih hibrida NASA-29 di Desa Oeteta, Kabupaten Kupang, NTT

\begin{tabular}{|c|c|c|c|c|}
\hline $\begin{array}{l}\text { Limbah } \\
\text { Jagung }\end{array}$ & $\begin{array}{l}\text { Luas } \\
\text { Area } \\
\text { (ha) }\end{array}$ & $\begin{array}{l}\text { Produksi } \\
\left(\mathrm{kg} \mathrm{ha}^{-1}\right)\end{array}$ & $\begin{array}{c}\text { Frekuensi } \\
\text { Panen }\end{array}$ & $\begin{array}{c}\text { Produksi } \\
\text { Limbah Segar } \\
\text { Jagung } \\
\left(\mathrm{kg} \mathrm{tahun}^{-1}\right)\end{array}$ \\
\hline $\begin{array}{l}\text { Jerami } \\
\text { (batang } \\
\text { dan } \\
\text { daun) }\end{array}$ & 7 & $32.221,50$ & $2 x$ & 451.101 \\
\hline Tongkol & 7 & $4.658,97$ & $2 x$ & $65.225,58$ \\
\hline $\begin{array}{l}\text { Kulit } \\
\text { jagung } \\
\text { (klobot) }\end{array}$ & 7 & 776,49 & $2 x$ & $10.870,86$ \\
\hline Total & & & & $527.197,44$ \\
\hline
\end{tabular}

http://journal.ipb.ac.id/index.php/jurnalintp 
karena memiliki beberapa keunggulan antara lain: tahan penyakit dan hama, produksi tinggi, panen cepat serta toleran terhadap berbagai jenis dan ketinggian lahan. Pemilihan jagung hibrida berdasarkan hasil produksi, penyakit, dan ketahanan serangga. Menurut penelitian Owens (2015) bahwa daun dari jagung hibrida memiliki kandungan Neutral Detergent Fiber (NDF), daya cerna NDF, dan kandungan lignin. Neutral Detergent Fiber (NDF) adalah indikator yang baik untuk mengukur serat dan konsumsi pakan.

Menurut Ayasan et al. (2018) menunjukkan bahwa kandungan nutrien tongkol jagung adalah 3,07\% protein kasar, 0,20\% lemak kasar, 29,05\% serat kasar, 1,69\% Ca, $0,06 \% \mathrm{PO}_{4}$, abu 2,15\% dan kadar air 4,80\%. Menurut Faesal (2013) tongkol jagung kering mengandung tongkol $87 \%$ bahan kering, 83\% TDN, dan 9,0\% protein kasar. Ayasan et.al (2018) melaporkan bahwa sekitar $46 \%$ tanaman jagung terdiri dari biji-bijian dan 54\% terdiri dari tangkai, sekam, daun, batang. Batang jagung pada umumnya merupakan pakan berkualitas rendah. Bahan kering batang jagung sebesar 89,85\%; protein kasar 3,79\%; NDF 67,42\% dan ADF 39,93\%. Ayasan et al. (2018) menjelaskan jerami jagung memiliki bahan kering 91\%, protein kasar 3,3\%; lemak kasar 2,2\%; NDF dan ADF masing-masing 69\% dan 43\%; lignin \% 8,9; abu kasar 8,4\% dan energi metabolik 1,50 Mcal kg-1. Lardy (2016) menyatakan sisa jagung yang tersisa setelah panen meliputi batang, daun, sekam dan tongkol. Proporsi tanaman jagung saat dewasa yaitu tongkol $8,2 \%$, bulir $45,9 \%$, klobot $7 \%$, daun $11,5 \%$, tangkai $27,5 \%$.

Dilihat dari karakteristik kandungan energinya, batang jagung dapat dikatakan sebagai bahan bakar dengan kepadatan energi yang cukup sedang, berkisar antara 17,2 MJ kg-1 dan 18,5 MJ kg-1 higher heating values (HHV) (Mullen, 2010). Mengenai pemanfaatan batang jagung sebagai pakan ternak ruminansia, batang jagung umumnya dianggap sebagai pakan ternak berkualitas rendah. Meskipun kandungan ligninnya agak rendah $(10,7 \pm 6,38 \%)$, ia juga memiliki kandungan protein yang rendah kurang dari 5\% (Darwish et al. 2012). Dilihat dari karakteristik energinya, tongkol jagung dapat dikategorikan sebagai bahan bakar dengan densitas energi sedang, berkisar antara 17,0 dan 18,9 MJ kg-1 HHV; nilai-nilai ini kurang lebih mendekati HHV batang jagung (Wang, 2010). Tongkol jagung adalah bahan pakan yang bernutrien rendah, kurang lebih mirip dengan jerami berkualitas rendah. Tongkol jagung mengandung protein yang rendah berkisar antara 0,88\%-9,81\%, dan sebagian besar tersusun dari serat dengan kandungan NDF lebih tinggi dari 68\%. Dibandingkan dengan data yang tersedia dari literatur, protein kasar berada pada level yang sama dengan Heuze et al. (2016), yaitu 1,9\%-8,8\% (Feedipedia, 2016).

\section{Kapasitas Tampung}

Berdasarkan penelitian di Desa Oeteta, Kabupaten Kupang, NTT, mampu menghasilkan bahan limbah tanaman jagung berupa jerami 451,08 kg tahun ${ }^{-1}$, tongkol jagung 65,24 kg tahun ${ }^{-1}$, dan klobot jagung 10,92 kg tahun $^{-1}$. Produksi limbah jagung yang tinggi dapat dimanfaatkan sebagai pakan ternak di Desa Oeteta, Kabupaten Kupang, NTT dan memungkinkan ternak dipelihara secara umbaran di lahan tanaman jagung. Perhitungan kapasitas tampung menentukan kemampuan sumber pakan ternak di Desa Oeteta dalam menampung ternak ruminansia.

Perhitungan kapasitas tampung ternak ruminansia di Desa Oeteta, Kabupaten Kupang, NTT dapat dilihat pada Tabel 3. Dengan asumsi konsumsi satu ekor sapi per hari bahan kering 3\% dari bobot badan. Menurut Ardiana et al. satu unit ternak setara dengan satu ekor sapi seberat $455 \mathrm{~kg}$ dan asumsi limbah yang digunakan mencapai $30 \%$ atau $40 \%$ sebagai pakan. Pakan digunakan untuk kehidupan, pertumbuhan, perkembangan dan reproduksi. Apabila disetarakan maka, satu unit ternak sama dengan satu sapi/ satu kerbau/ tujuh kambing/ tujuh domba. Semakin tinggi produksi limbah pada lahan jagung, maka semakin tinggi pula kemampuan menampung sejumlah ternak untuk makanan ternak pada waktu tertentu (Resa 2010).

Besarnya produksi limbah jagung di Desa Oeteta, Kabupaten Kupang, NTT berdasarkan produksi limbah jagung adalah 527.197,44 kg tahun ${ }^{-1}$. Berdasarkan produksi limbah jagung dengan kisaran penggunaan $30 \%$ pada ternak memiliki daya kapasitas tampung sebesar 352,71 setara dengan 352 ekor sapi potong dan 2.464 ekor kambing, sedangkan kisaran pemanfaatan $40 \%$ pada ternak memiliki daya kapasitas tampung ternak sapi 264,54 setara untuk 264 ekor sapi potong dan 1.851 ekor kambing. Berdasarkan hasil perhitungan daya kapasitas tampung, bahan kering, limbah jagung, dan kebutuhan konsumsi menunjukkan bahwa limbah jagung mampu memenuhi kebutuhan pakan ternak di Desa Oeteta, Kabupaten Kupang, NTT.

Pengembangan ternak sapi di NTT didukung oleh potensi sumber daya lokal dan lahan yang luas. Namun demikian, pemeliharaan sapi di NTT sebagian besar masih menggunakan sistem usaha tradisional dengan produktivitas relatif rendah (Ratnawaty 2020). Menurut Achadri et al. (2020), Sapi Bali sebagian besar dipelihara secara ekstensif dengan cara digembalakan pada padang penggembalaan alam. Padang penggembalaan ini, jika dilakukan perbaikan pemeliharaan tanaman dengan baik, akan meningkatkan kapasitas tampungnya. Namun, jika padang penggembalaan tersebut tidak dikelola dengan baik, akan berdampak pada menurunnya ketersediaan pakan terutama musim kemarau. Hal ini

Tabel 3 Kapasitas tampung pakan ternak terhadap populasi ternak

\begin{tabular}{|c|c|c|c|c|}
\hline \multirow[t]{2}{*}{$\begin{array}{l}\text { Konsumsi } \\
\text { Pakan }\end{array}$} & \multirow{2}{*}{$\begin{array}{c}\text { Bahan } \\
\text { Kering } \\
\left(\text { kg tahun }^{-1}\right)\end{array}$} & \multirow{2}{*}{$\begin{array}{l}\text { Produksi } \\
\text { Limbah } \\
\left(\text { kg tahun }^{-1}\right)\end{array}$} & \multicolumn{2}{|c|}{$\begin{array}{c}\text { Kapasitas Tampung } \\
\text { (UT) }\end{array}$} \\
\hline & & & $\begin{array}{l}\text { Sapi/ } \\
\text { Kerbau }\end{array}$ & $\begin{array}{c}\text { Kambing/ } \\
\text { Domba }\end{array}$ \\
\hline $30 \%$ & 1494.7 & $527.197,44$ & 352 & 2.464 \\
\hline $40 \%$ & 1992.9 & $527.197,44$ & 264 & 1.851 \\
\hline
\end{tabular}


dapat berdampak pada relatif rendahnya produktivitas ternak.

\section{Nilai Potensi Limbah Jagung}

Sebagian besar limbah memiliki nilai potensial sebagai bahan pakan ternak. Nilai potensial ini akan bermanfaat secara ekonomi terutama di negara berkembang, dimana pakan ternak tradisional dan mahal lainnya dapat diganti. Limbah jagung harus dikembangkan berdasarkan penelitian fundamental dan terapan di bidang ilmu dan teknologi pengolahan pakan. Penelitian perlu dilakukan, meliputi: pemrosesan pakan, uji kimia dan nutrisi, serta pengaruhnya terhadap kinerja pertumbuhan ternak. Pemanfaatan limbah jagung yang kaya nutrien untuk produksi pakan ternak akan menurunkan biaya pakan dan menurunkan harga produk hewan. Ini juga akan berkontribusi pada swasembada nutrien dari limbah lokal yang tersedia.

Sistem produksi pakan dari limbah dapat menciptakan integrasi vertikal, produksi ternak saling melengkapi dan dapat memecahkan masalah limbah dan pencemaran lingkungan. Pemanfaatan limbah jagung untuk pakan ternak akan menjadi dasar yang kuat untuk pengembangan teknologi dan pengelolaan peternakan yang berkelanjutan. Pemberian makan yang tepat meningkatkan kekebalan, kesehatan, kesejahteraan, dan kinerja reproduksi hewan ternak (Laura et al. 2020); memungkinkan produktivitas yang lebih tinggi (AbsalónMedina et al. 2012) dan berkontribusi pada kelestarian lingkungan dengan mengubah energi dan nutrien dari bahan yang tidak dapat digunakan oleh manusia menjadi makanan bergizi tinggi. Sebagian besar pakan yang dikonsumsi dari ternak berasal dari daerah tersebut atau dalam produk samping (by-product) dari kegiatan agroindustri yang dapat dimanfaatkan untuk bahan pakan (Balehegn et al. 2020).

\section{SIMPULAN}

Provinsi NTT merupakan daerah dataran kering iklim yang dapat memanfaatkan potensi limbah jagung sebagai pakan ternak. Pakan dari limbah jagung yang tersedia di Desa Oeteta, Kabupaten Kupang, NTT, yaitu luasan lahan 7 ha dengan konsumsi pakan 40\% dapat mencukupi daya kapasitas tampung setara dengan 264 ekor sapi.

\section{UCAPAN TERIMA KASIH}

Penulis mengucapkan terima kasih yang sebesarbesarnya atas dukungan dana untuk penelitian ini oleh Balai Pengkajian Teknologi Pertanian (BPTP), Nusa Tenggara Timur (NTT), Indonesia. Terima kasih kami ucapkan kepada Dr. Procula Rudlof Matitaputty, S.Pt, M.Si selaku Kepala BPTP NTT, Prof.Ir. Jacob Nulik, M.Sc, Ph.D, Dr. Ir. Sophia Ratnawaty, M.Si, Ir. Debora Kana Hau, M.Si, Ir. Ati Rubianti, M.Si atas motivasi dan dukungannya. Kami juga berterima kasih kepada kelompok tani Sehati di Desa Oeteta, Kabupaten Kupang Timur, NTT yang bersedia berpartisipasi dalam penelitian ini

\section{DAFTAR PUSTAKA}

Abadi M, Firman N, Surahmanto, Abdul R, \& Fatmawati. 2019. The carrying capacity of crop as cow and goat feed in Muna Barat Regency. Bulletin of Animal Science, 43 (3): 151-157.

Absalón-Medina VA, Nicholson CF, Blake RW, Fox DG, Juárez-Lagunes FI L, Canudas-Lara EG, Maldonado, \& Rueda-Maldonado BL. 2012. Economic analysis of alternative nutritional management of dualpurpose cow herds in central coastal Veracruz, Mexico. Tropical Animal Health and Production 44 (6) :115-143.

Achadri Y, Sendow CJB \& Ratnawaty S. 2020. Manajemen pemeliharaan untuk menurunkan tingkat mortalitas pedet sapi Bali. Prosiding Seminar Nasional Teknologi Peternakan dan Veteriner. Jember (ID): Fakultas Peternakan Universitas Jember

Adijaya IN, Budiari NLG \& Kertawirawan IPA. 2018. Potential production and waste for livestock cattle food Three hybrid maize on the young harvest. Proceeding The Second International Conference on Food and Agriculture. Bali (ID): Politeknik Negeri Jember.

Ardiana IW , Widodo Y \& Liman. 2015. Feed potential of waste Corn (Zea mays L.) in the Braja Harjosari Village Braja Selebah Subdistrict East Lampung. Jurnal Ilmiah Peternakan Terpadu 3(3) : 170-174.

Ayasan T \& Aykanat S. 2018. Possibilities of use of corn stalk and straw in animal feeding. $10^{\text {th }}$ International Animal Science Conference. Antalya (Turkey): Turkish Federation for Animal Science

Balehegn M, Duncan A, Tolera A, Ayantunde A \& Issa S. 2020. Improving adoption of technologies and interventions for increasing supply of quality livestock feed in low and middle income countries. Vol. ke 26. New York (US): Global Food Security,

Bracco S, Calicioglu, Gomez SJ \& Flammini A. 2018. Assessing the contribution of bioeconomy to the total economy: a review of $\begin{array}{llll}\text { national frameworks. Sustainability } 10 \quad \text { (6): } 1698 . & \end{array}$ https://doi.org/10.3390/su10061698

Darwish GAMA, Bakr AA \& Abdallah MMF. 2012. Nutritional value upgrading of maize stalk by using Pleurotus ostreatus and Saccharomyces cerevisiae in solid state fermentation. Annals of Agricultural Sciences, 57 (1) : 47-51.

Bryan E, Ringler C, Okoba B, Roncoli C, Silvestri S \& Herrero M. 2013. Adapting agriculture to climate change in Kenya: household strategies and determinants. Journal of Environmental Management 114 (2): 26-35.

European Commission [EC]. 2015. EIP-AGRI Workshop "Opportunities for Agriculture and Forestry in the Circular Economy". Workshop Report 28-29 october 2015. Brussels, Belgium. (Internet). (Cited 2020 September 11). Available from https://ec.europa.eu/eip/agriculture/sites/agrieip/files/eipagri_ ws_circular_economy_final_report_2015_en.pdf

Faesal. 2013. Pengolahan limbah tanaman jagung untuk pakan ternak sapi potong. Makalah. Seminar Nasional Inovasi Teknologi Pertanian. Banjar Baru (ID): BPTP Kalimantan Selatan, Badan Litbang Pertanian Kementerian Pertanian.

Feedipedia. 2016. Animal feed resources information system. (Internet). (Cited 2020 Agustus 19). Available from http://www.feedipedia.org.

Herrero M, Henderson B, Havlík P, Thornton PK, Conant RT, Smith P, Wirsenius S, Hristov AN, Gerber P, Gill M, Butterbach-Bahl, Valin H, Garnett T, \& Stehfest E. 2016. Greenhouse gas mitigation potentials in the livestock sector. Nature Climate Change, 6 (1): 452-461.

Kaizzi KC, Mohammed MB \& Nouri M. 2017. Fertilizer Use Optimization: Principles and Approach. C.S. Wortmann (Ed.), Fertilizer Use Optimization in Sub-Saharan Africa, Nairobi (KE): CAB International

Kapa MJ, 2019. Social and economic analysis of food crops and beef cattle sub systems in the dry land area of Kupang Regency, East Nusa Tenggara Province, Indonesia. International Conference on Animal Production for Food Sustainability, IOP Conf. Series: Earth and Environmental Science 287 : 1-6. 
Keban A, Lalus MF \& Sogen JG. 2019. Strategy for increasing farmers income through dry Land resources combination in Kupang District of Nusa Tenggara Timur. Journal of. Russian of Agriculture and Socio-Economic Sciences. 91 (7): 349-357.

Lardy, G. 2016. Utilizing Corn Residue in Beef Cattle Diets. North Dakota (U.S): North Dakota State University, Department of Agriculture

Laura Y, Adyatama, Indra, Achadri Y \& Airin CM. 2020. The effect of different physiological reproduction conditions on estradiol (E2) residues in local raw milk. Journal of Pakistan of Nutrition. 19 (3): 127-131.

Midega CAO, Salifu D, Bruce TJ, Pittchar J, Pickett J \&, Khan ZR. 2015. Cumulative effects and economic benefits of intercropping maize with food legumes on Striga hermonthica infestation. Journal of Field Crops Research. 155 (2): 144-152.

Mullen CA, Boateng AA, Goldberg NM, Lima IM, Laird DA \& Hicks KB. 2010. Bio-oil and bio-char production from corn cobs and stover by fast pyrolysis. Journal of Biomass and Bioenergy. 34 (1): 67-74.

Nulik J, Dalgliesh N, Cox K \& Gabb S. 2013. Integrating Herbaceous Legumes into Crop and Livestock System in Eastern Indonesia. Australia: ACIAR.

Owens F. 2015. Corn Genetics and Animal Feeding Value. IA: Pioneer HiBred International, Inc., Johnston.

Parakkasi A. 2006. Ilmu Nutrisi dan Makanan Ternak Monogastrik. Jakarta (ID): Universitas Indonesia Press

Pomolango R, Kaunang CL, \& Elly FH. 2016. Analisis produksi limbah tanaman pangan sebagai pakan ternak sapi di Kabupaten Bolang
Mongondow Utara. Zootec Jurnal. 36 (1): 302-311. doi:10.35792/zot.36.2.2016.12413

Rahman R, Hafid H, Rahadi S, Aka R, Anas A \& Baena S. 2015. The nutrients potential of agricultural waste as feed of ruminants in Southeast Sulawesi. Proceeding of International Seminar "Improving Tropical Animal Production for Food Security". Kendari (ID): Universitas Halu Oleo.

Ratnawaty Sophia, Yanuar Achadri, Medo Kote. 2020. Pengembangan peternakan sapi Bali di desa Raknamo Nusa Tenggara Timur. Prosiding Seminar Nasional Akselerasi Inovasi Pertanian Era Industri 4.0 mendukung Kawasan Pertanian Sejahtera (SAPIRA), Gorontalo ID): Balai Besar Pengkajian dan Pengembanagn Teknolog, Litbang Pertanian doi:10.13140/RG.2.2.11080.06406

Resa, E. 2010. Potensi pakan kosentrat asal tanaman padi dan jagung di Kota Metro Provinsi Lampung (Skripsi) Bandar Lampung (ID) : Universitas Lampung

Rivin J, Miller Z \& Matel O. 2014. Using Food Waste as Livestock Feed Wiscounsin (US): University of Wisconsin-Extension.

Sabiti EN. 2011. Utilizing Agricultural Waste to Enhance Food Security and Converse the Environment. Kampala (UG): Department of Agricultural Production, Makerere University

Wang LK, Ivanov V, Tay JH \& Hung YT. 2010. Handbook of Environmental Engineering: Environmental Biotechnology, ValueAdded Biotechnological Products from Organic Wastes. Hamana Press. 